Pacific Northwest

National Laboratory

Operated by Battelle for the

U.S. Department of Energy

\title{
Dangerous Waste Characteristics of Waste from Hanford Tank 241-S-109
}

\author{
J. M. Tingey \\ G. H. Bryan \\ J. R. Deschane
}

October 2004

Prepared for the U.S. Department of Energy under Contract DE-AC05 -76RL01830 


\title{
DISCLAIMER
}

This report was prepared as an account of work sponsored by an agency of the United States Government. Neither the United States Government nor any agency thereof, nor Battelle Memorial Institute, nor any of their employees, makes any warranty, express or implied, or assumes any legal liability or responsibility for the accuracy, completeness, or usefulness of any information, apparatus, product, or process disclosed, or represents that its use would not infringe privately owned rights. Reference herein to any specific commercial product, process, or service by trade name, trademark, manufacturer, or otherwise does not necessarily constitute or imply its endorsement, recommendation, or favoring by the United States Government or any agency thereof, or Battelle Memorial Institute. The views and opinions of authors expressed herein do not necessarily state or reflect those of the United States Government or any agency thereof.

\author{
PACIFIC NORTHWEST NATIONAL LABORATORY \\ operated by \\ BATTELLE \\ for the \\ UNITED STATES DEPARTMENT OF ENERGY \\ under Contract DE-AC06-76RL01830
}

Ty 


\title{
Dangerous Waste Characteristics of Waste from Hanford Tank 241-S-109
}

\author{
JM Tingey \\ GH Bryan \\ JR Deschane
}

October 2004

Prepared for

the U.S. Department of Energy

under Contract DE-AC06-76RL01830

Pacific Northwest National Laboratory

Richland, WA 99352 


\section{Executive Summary}

Existing analytical data on samples taken from Hanford Tank 241-S-109 (S-109), along with process knowledge of the wastes transferred to this tank, were reviewed to determine whether the dangerous waste characteristics currently assigned to all wastes in Hanford underground storage tanks are applicable to S-109 waste.

Supplemental technologies are being examined to accelerate the Hanford tank waste cleanup mission and to accomplish waste treatment in a safer and more efficient way. The Bulk Vitrification System (BVS) is one treatment technology being considered to assist in immobilizing the low-activity tank waste. The goals of the supplemental technologies are to reduce costs, conserve double-shell tank space, and meet the scheduled tank waste processing completion date of 2028. The effectiveness of the bulk vitrification process will be demonstrated at a research and development facility known as the Demonstration Bulk Vitrification System (DBVS). The DBVS will test technologies using dissolved saltcake waste from Tank S-109.

The dangerous waste characteristics being considered (and the dangerous waste codes) include ignitability (D001), corrosivity (D002), and reactivity (D003). The analytical data reviewed with respect to waste code D001 include differential scanning calorimetry (DSC) results and the percent of the lower flammability limit (LFL) calculated from the composition of the headspace. Concentrations of sulfur, sulfate, and cyanide, the composition of headspace (vapor space), and DSC results were reviewed for waste code D003; and pH was reviewed for D002. Data on mercury concentrations were also included. DSC results were used to determine the energetics of the tank wastes as a function of temperature.

Exothermic transitions were observed in a limited number of samples from Tank S-109. Exothermic transitions were broad peaks with small amplitudes at temperatures exceeding $200^{\circ} \mathrm{C}$, indicating that explosive reactions or ignition hazards at standard temperatures and pressures are unlikely (waste codes D001 and D003).

Sulfur and sulfate analyses indicated that the majority of the sulfur in the waste is present as sulfate. Based on the $\mathrm{pH}$ of the tank wastes, the sulfate is stable and will not react to form sulfide. Thus, this waste should not be considered sulfide-bearing (waste code D003). Cyanide analyses were not available, but process history indicates that no cyanide-containing process or waste streams were transferred to this tank. Thus, this waste should not be considered cyanide-bearing (waste code D003). The $\mathrm{pH}$ of the waste in Tank S-109 is 13, which exceeds the 12.5 limit considered characteristic of corrosive wastes; therefore, this waste must be considered corrosive (waste code D002).

Gas analysis of the headspace vapors in this tank indicates that all of the toxic vapors except ammonia are well below the threshold limit value-time weighted average (TLV-TWA) (waste code D003). The dilution required (a factor of 1.9) is less than that currently planned for retrieval of this waste (3.37 to 1 water to waste ratio); therefore, the process waste retrieved from the tank should not generate ammonia gas at concentrations harmful to human health.

Analysis of the existing characterization data from core, grab, and vapor samples from Tank S-109 thus supports the removal of the dangerous waste codes for ignitability (D001) and reactivity (D003). 


\section{Table of Contents}

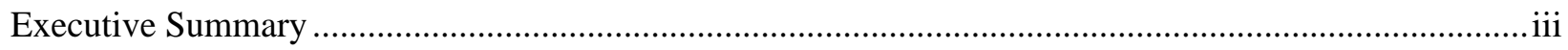

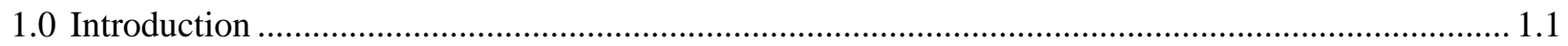

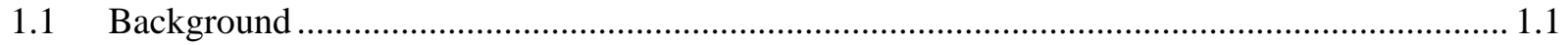

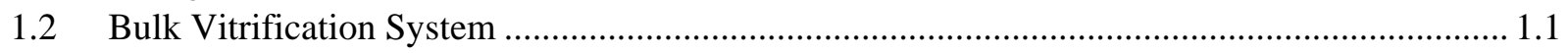

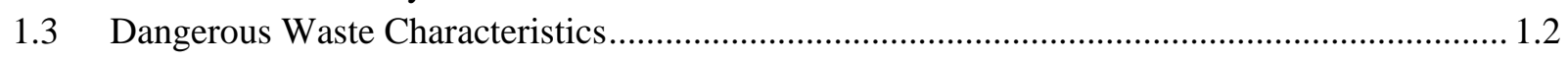

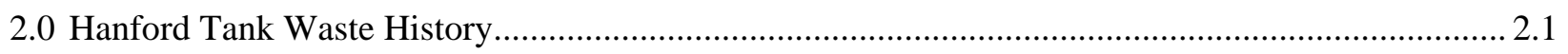

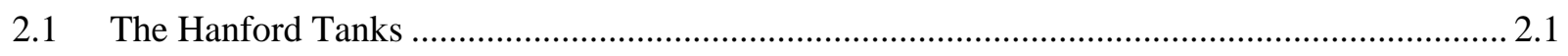

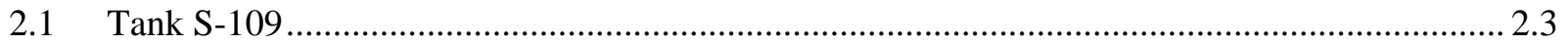

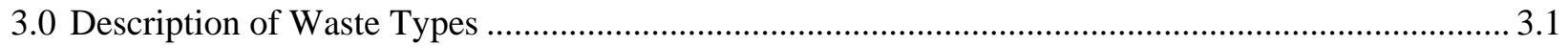

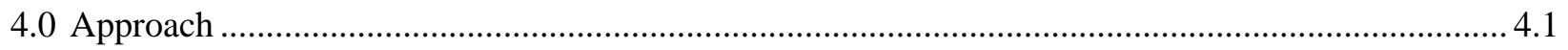

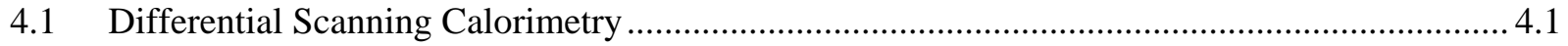

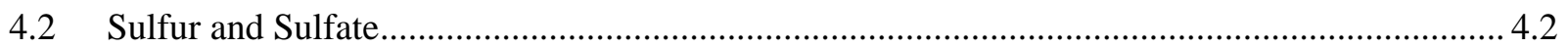

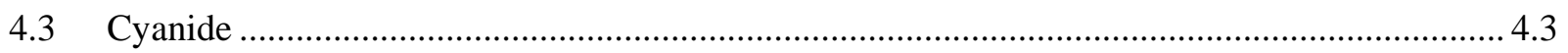

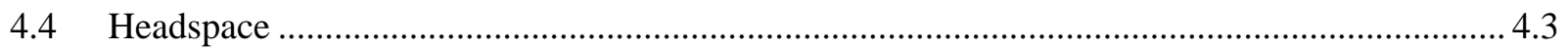

$4.5 \mathrm{pH}$

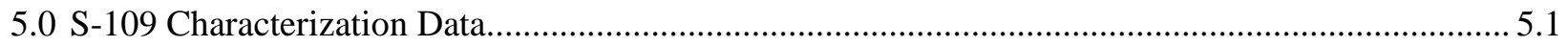

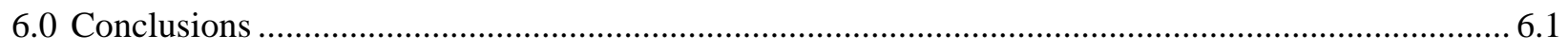

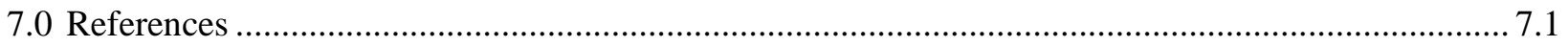




\section{Figures}

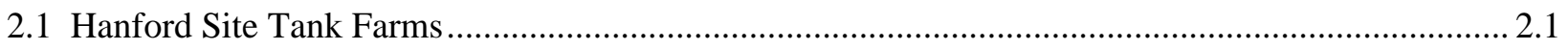

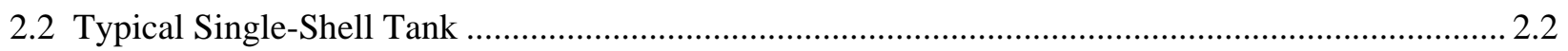

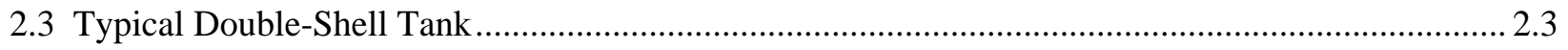

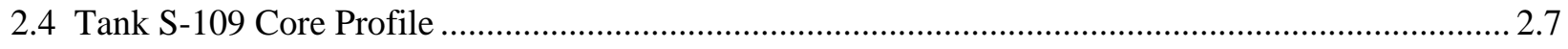

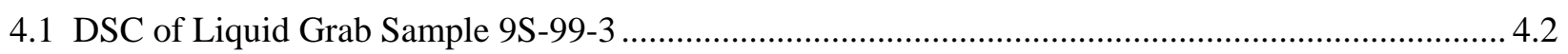

\section{Tables}

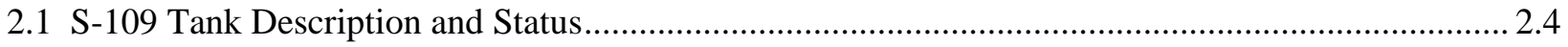

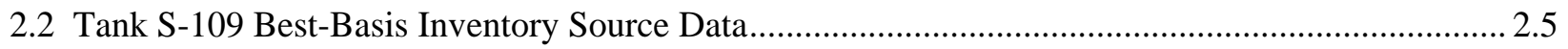

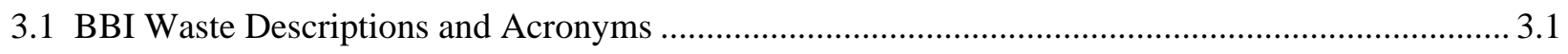

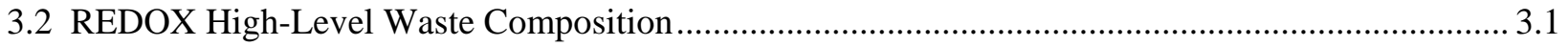

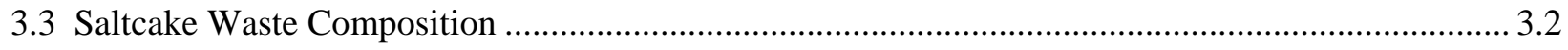

4.1 Analyses Reviewed in Determining Dangerous Waste Characteristics............................................ 4.1

4.2 Threshold Limit Values for Selected Headspace Gases ................................................................ 4.4

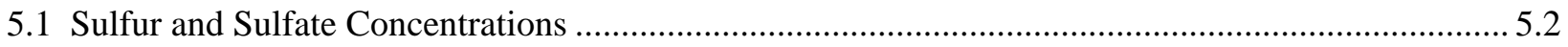

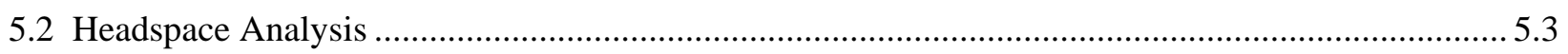




\subsection{Introduction}

Several dangerous waste characteristics have been assigned to the wastes found in the Hanford underground storage tanks. These waste characteristics and their dangerous waste codes include ignitability (D001), corrosivity (D002), and reactivity (D003). Existing analytical data for samples taken from Hanford Tank 241-S-109 (S-109), along with process knowledge of the wastes transferred to this tank, have been reviewed to determine whether these waste codes are applicable to this tank waste.

\subsection{Background}

Radioactive wastes from defense operations on the Hanford Site were accumulated in 177 underground storage tanks beginning in the 1940s. These wastes came from three processes for recovering uranium and plutonium from irradiated uranium fuel, three processes for recovering radionuclides from the waste, miscellaneous other sources such as laboratories and reactor decontamination solutions, and production and waste management operations. The acid waste streams were made $\mathrm{pH}$ neutral or alkaline before being transferred into the tanks, resulting in the formation of metal hydroxide sludges. Evaporation of water from these wastes concentrated them to form crystallized salts and salt-rich alkaline solutions.

The U.S. Department of Energy Office of River Protection (DOE-ORP) is responsible for managing the safe storage, treatment, and disposal of these wastes. The tanks contain approximately 53 million gallons of highly radioactive wastes and approximately 190 million curies of radioactivity. Current disposition strategies for the majority of these wastes include retrieval of the waste from the tanks, pretreatment, and vitrification. A Waste Treatment Plant (WTP) that includes immobilization capability is being designed and built to perform these operations.

Supplemental technologies are being examined to accelerate the Hanford tank waste cleanup mission and to accomplish the waste treatment in a safer and more efficient manner. A Bulk Vitrification System (BVS) is being pursued as an additional means to immobilize the low-activity waste (LAW) while reducing costs, conserving double-shell tank (DST) space, and helping meet the scheduled tank waste processing completion date of 2028. To demonstrate the effectiveness of the bulk vitrification process, a research and development facility known as the Demonstration Bulk Vitrification System (DBVS) is being built. The DBVS will use dissolved saltcake waste from Tank S-109.

\subsection{Bulk Vitrification System}

To assist in immobilizing tank waste, reducing costs, conserving DST space, and meeting the scheduled completion date of 2028 (Tri-Party Agreement, M-62-00), the BVS is being evaluated for processing LAW from Hanford's underground tanks. The primary technology to be used for the BVS is In-Container Vitrification (ICV ${ }^{\mathrm{TM}}$ ), a process that involves batch treatment of waste in a refractory-lined steel container. The DBVS will be deployed to fully demonstrate the bulk vitrification process on LAW prior to full-scale implementation of the BVS. 
The DBVS will be deployed near the 241-S tank farm in the 200 West Area of the Hanford Site. The waste selected for immobilization with the DBVS will originate from Tank S-109. The LAW in Tank S-109 will be retrieved such that insoluble solids and waste with a high concentration of ${ }^{137}$ Cs will not be transferred to the DBVS. During processing, liquid waste will be mixed with appropriate glass formers, and excess water will be removed from the mixture. The mixture will be transported and distributed into a waste container where electrodes penetrating the waste mixture will vitrify the waste via joule heating.

The waste container is expected to be a roll-off type box. Before the waste is placed in it, the box will be lined with insulation and refractory material. The lid will be sealed onto the box before waste is added, and the lid will have several ports to accommodate waste input lines, the electrical connections of the electrodes, and a vent for off-gas generated during the melt process. After the vitrification process is complete, soil will be added through one of the ports to fill the container. The box will then be cooled and externally decontaminated as required.

\subsection{Dangerous Waste Characteristics}

The dangerous waste characteristics described in the Dangerous Waste Regulations published by the Washington State Department of Ecology (Ecology 2003) that are of interest in this study and assigned to Tank S-109 include ignitability, corrosivity, and reactivity. Several other dangerous waste characteristics are assigned to Tank S-109 but were not included in this analysis. Only the characteristics of ignitability (D001), corrosivity (D002), and reactivity (D003) associated with the waste from Tank S-109 were considered.

Hanford tank wastes exhibit the characteristics of ignitability if a representative sample of the waste is "capable, under standard temperature and pressure, of causing a fire through friction, absorption of moisture or spontaneous chemical changes and, when ignited, burns so vigorously and persistently that it creates a hazard" or "is an oxidizer." The other criteria described in the Dangerous Waste Regulations do not apply because the liquids associated with the tank waste are aqueous solutions containing less than 24 percent alcohol by volume, and the tank wastes are not compressed gases.

Wastes that have $\mathrm{pH}$ less than or equal to 2 or greater than or equal to 12.5 are designated as dangerous wastes due to corrosivity and assigned the dangerous waste number of D002 or WSC2. A designation of WSC2 is assigned when the $\mathrm{pH}$ of the liquid generated from mixing solid or semisolid waste with equal amounts of water is less than or equal to 2 or greater than or equal to 12.5 . If the $\mathrm{pH}$ measured directly in the waste is less than or equal to 2 or greater than or equal to 12.5, the waste is corrosive and assigned the dangerous waste designation D002.

Several waste properties must be considered to determine whether the waste exhibits the characteristic of reactivity, including a representative sample of the waste 1) being normally unstable and readily undergoing a violent change without detonation; 2) reacting violently with water; 3) forming potentially explosive mixtures with water; 4) generating toxic gases, fumes, or vapors at concentrations sufficient to present a danger to human health or the environment when mixed with water; 5) containing cyanide or sulfide, which, when exposed to $\mathrm{pH}$ conditions between 2 and 12.5, can generate toxic gases, vapors, or fumes at concentrations sufficient to present a danger to human health or the environment; 6) being readily capable of detonation or explosion if subjected to a strong initiating source or if heated 
under confinement; 7) being readily capable of detonation or explosive decomposition or reaction at standard temperature and pressure; and 8) being a forbidden explosive. These properties deal primarily with the energetics of the waste or the generation of toxic gases from the waste. 


\subsection{Hanford Tank Waste History}

\subsection{The Hanford Tanks}

Between 1943 and 1964, 149 single-shell tanks (SSTs) were built for storing the radioactive wastes generated by chemical processing of irradiated reactor fuels. These SSTs are located in 12 tank farms in the 200 West and 200 East Areas on the Hanford Site. Figure 2.1 is a reference schematic of these SST farms. The capacities of the SSTs range from $208 \mathrm{~m}^{3}$ (55,000 gallons) to 3,785 $\mathrm{m}^{3}$ (1,000,000 gallons). Carbon steel lines the bottom and sides of the reinforced concrete shell of each tank. The tanks are below grade with at least 6 feet of soil covering the top of tank. Figure 2.2 is a sketch of a typical SST.

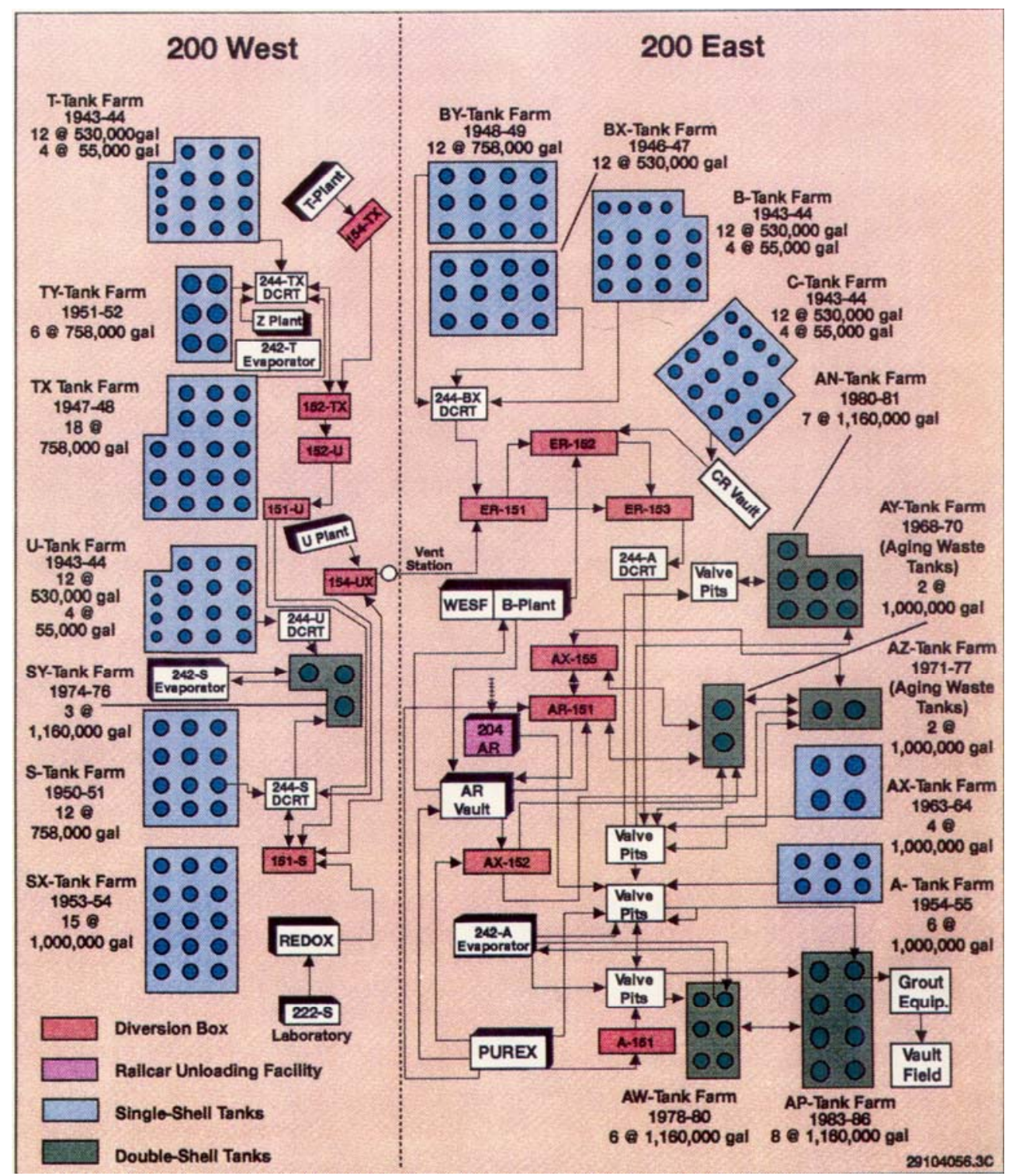

Figure 2.1. Hanford Site Tank Farms 


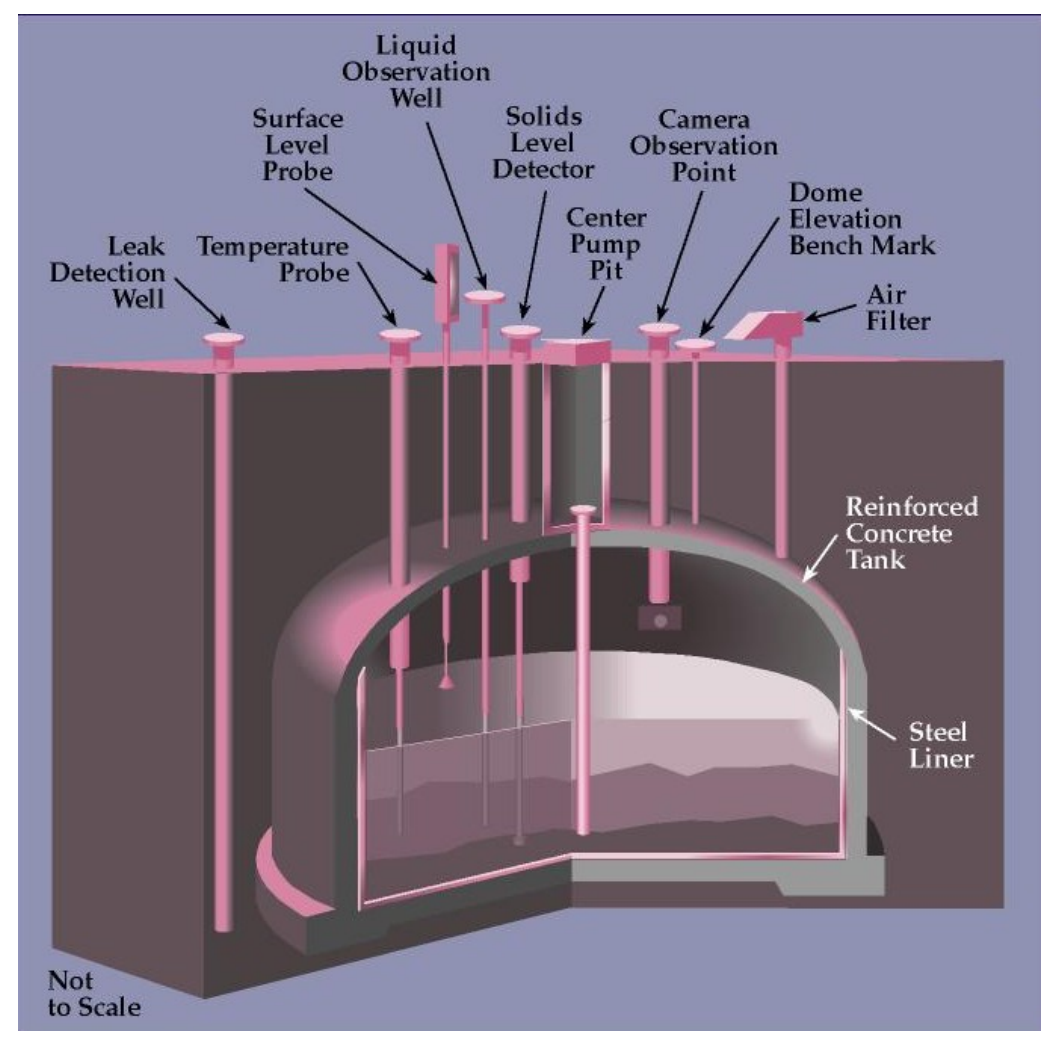

Figure 2.2. Typical Single-Shell Tank

Many of the SSTs were built in "cascades" of three, four, or six tanks. Inlet and overflow lines in these tanks are positioned near the top of the carbon-steel liner. Waste was transferred to the first tank of the cascade and allowed to overflow into the successive tanks of the cascade through the overflow lines.

Twenty-eight DSTs were constructed between 1968 and 1986 to receive liquid radioactive wastes generated by decommissioning and cleanup operations in the 100, 200, 300, and 400 areas of the Hanford Site. These operations included the transfer of pumpable liquids from the SSTs to the DSTs. Each DST consisted of three concentric structures. The outer tank is reinforced concrete lined with a secondary carbon steel liner, which extends along the concrete tank haunch and dome to the inner tank haunch. The inner structure is a free-standing, completely enclosed carbon steel tank situated within the secondary liner and separated by an annular space. Leak detection and liquid level detection devices are placed in this annular space. Figure 2.3 is a sketch of a typical DST.

Access to the wastes inside the tank is provided by risers that penetrate the dome of the tanks. The risers vary in diameter from 4 to 42 inches, and the number and size of the risers vary from tank to tank. Both sampling and monitoring are performed through these risers, many of which are filled with monitoring instrumentation that limits the locations at which the tank can be sampled.

Several methods have been used at the tank farms to obtain samples of the tank waste. The primary sampling methods include core sampling, grab sampling (also called Bottle-on-a-String), vapor space (headspace) sampling, and auger sampling. 


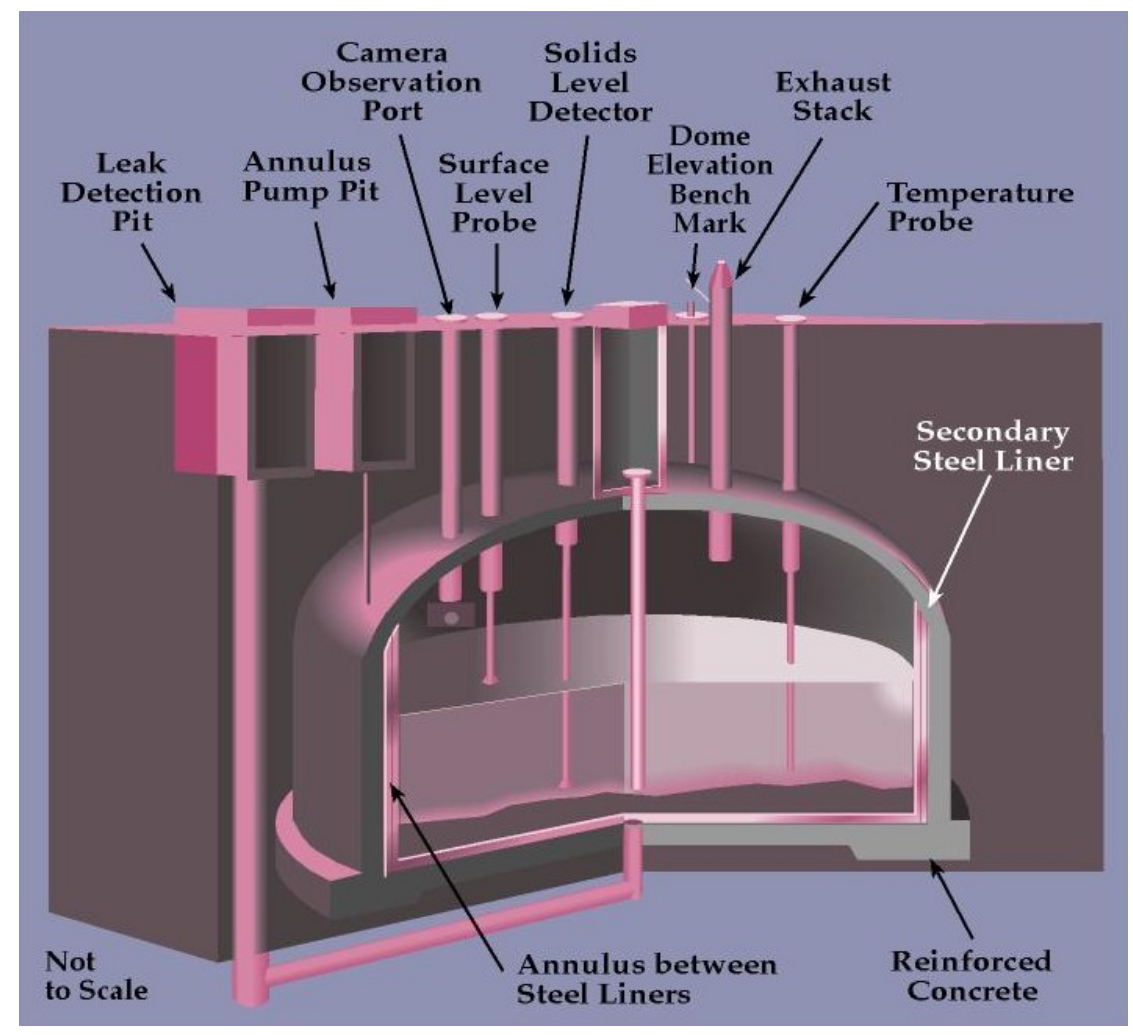

Figure 2.3. Typical Double-Shell Tank

Core samples are solid or liquid samples taken in 19-inch segments throughout the depth of the waste. Core samples are obtained from the tanks using a specially designed core-drilling truck and a sampling device that is either pushed or rotated through the waste. Core samples provide data on the variation in the composition and properties of the waste as a function of depth in the tank.

Grab samples are liquid or soft slurry samples of the waste that are taken from various depths in the liquid waste. A stoppered bottle is lowered to the desired depth in the tank, and the stopper is removed. The bottle fills with the liquid or slurry and then is retrieved from the tank.

Vapor space or headspace samples are gas samples obtained at various heights above the surface of the waste in the tank. The vapor is collected in Sorbent tubes, SUMMA canisters, or a cryogenic trap. The samples are analyzed in the laboratory by gas chromatography with a mass spectrometer as the detector (GC/MS) or by a gas mass spectrometer. Key analytes are reported along with any other gases that are observed in the samples.

\subsection{Tank S-109}

The S tank farm was constructed between 1950 and 1951 in the 200 West Area and contains 12 100-series tanks (Brevick et al. 1997). Tank S-109 has a design capacity of 2,870 kL (758 kgal), a

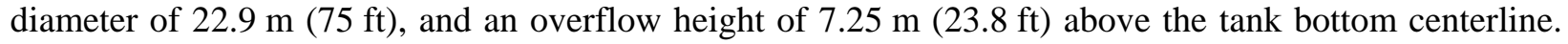
Tank S-109 is passively ventilated and was originally designed to be used as a concentrated waste holding 
tank. The tank is the third in a three-tank cascade that includes S-107, S-108, and S-109. Additional tank descriptive material is located in Field (1999). Table 2.1 presents a description and status of the tank as of April 1, 2004.

Table 2.1. S-109 Tank Description and Status

\begin{tabular}{|c|c|}
\hline \multicolumn{2}{|c|}{ Tank Description } \\
\hline Type & Single Shell \\
\hline Year constructed & 1950-1951 \\
\hline Placed in service & 12/1952 \\
\hline Diameter & $22.9 \mathrm{~m} \mathrm{(75 \textrm {ft } )}$ \\
\hline Operating depth & $698.5 \mathrm{~cm}$ (275 in.) \\
\hline Design capacity & 2869 kL (758 kgal) \\
\hline Bottom shape & Dish \\
\hline Ventilation & Passive \\
\hline \multicolumn{2}{|c|}{ Tank Status (as of $4 / 1 / 2004$ ) } \\
\hline Total waste volume & 2017 kL (533 kgal) \\
\hline Supernatant volume & $0 \mathrm{~kL}(0 \mathrm{kgal})$ \\
\hline Saltcake liquid volume & $63 \mathrm{~kL}$ (17 kgal) \\
\hline Saltcake solid volume & 1905 kL (503 kgal) \\
\hline Sludge volume & $49 \mathrm{~kL}(13 \mathrm{kgal})$ \\
\hline Surface level (4/1/2004) & $433.9 \mathrm{~cm}$ (170.8 in.) \\
\hline PCSACS surface level (7/27/2004) & $433.9 \mathrm{~cm}$ (170.8 in.) \\
\hline Integrity & Sound \\
\hline \multicolumn{2}{|c|}{ Sampling Dates } \\
\hline \multirow{2}{*}{ Core samples } & 6/21/1996-7/16/1996 \\
\hline & 7/2/1996-7/12/1996 \\
\hline Grab samples & 7/28/1999-7/28/1999 \\
\hline Vapor samples & 6/4/1996 \\
\hline \multicolumn{2}{|c|}{ Service Status } \\
\hline Last waste received & September 1974 \\
\hline Declared inactive & 1979 \\
\hline Interim stabilization & $6 / 11 / 2001$ \\
\hline
\end{tabular}

Tank S-109 first received waste on December 24, 1952 and was used to store REDOX salt waste from December 1952 through February 1974. The REDOX salt waste was removed from Tank S-109 and concentrated in the 242-S Evaporator between November 1973 and February 1974. The REDOX waste from S-109 was then stored in Tanks S-103, S-105, and S-106.

In February 1974, a heel of REDOX sludge (13,000 gallons) and salt waste (66,000 gallons) remained in Tank S-109. The tank was used to receive concentrated salt waste from the 242-S Evaporator from February through September 1974. The feed to the 242-S Evaporator during this period was from numerous single-shell tanks in the 200 East and 200 West Areas. By September 30, 1974, Tank S-109 was filled with approximately 653,000-gallons of solids (principally saltcake) and 47,000-gallons of 
supernatant liquid. However, the quantity of saltcake solids and supernatant could not be precisely measured. "Due to the characteristics of the solids in the bottoms tanks and the inability to measure them precisely, there is a significant degree of uncertainty in the liquid-to-solid ratio of the S Farm Tanks."(a) Records indicate that no further wastes were added to S-109 after September $1974 .^{\text {(b) }}$

Tank S-109 was stabilized and removed from service in 1979, partially isolated in December 1982, and is currently listed as sound and inactive. A jet pump was installed, and it removed a total of $855 \mathrm{~kL}$ (226 kgal) of supernatant liquid between 1978 and 1985. A net interstitial liquid volume of $128 \mathrm{~kL}$ (34-kgal) was saltwell-pumped to Tank SY-102 between September 23, 2000 and January 28, 2001. The tank was declared interim stabilized on June 11, 2001. (c) The tank contains 2,017 kL (533 kgal) of waste comprising a saltcake layer with an underlying sludge layer at the base of the waste profile (Hill et al. 1995).

The Best-Basis Inventory (BBI) for Tank S-109 incorporates sample and template information on the waste types currently in the tank (see Table 2.2). Templates are based on sampling data from tanks that contain the same waste type as S-109 supplemented with Hanford Defined Waste (HDW) model (Agnew et al. 1997) data.

Table 2.2. Tank S-109 Best-Basis Inventory Source Data

\begin{tabular}{|c|c|c|}
\hline Waste Phase & $\begin{array}{l}\text { Waste } \\
\text { Type }^{(a)}\end{array}$ & Associated Volume \\
\hline Saltcake solid & S1-SltCk & 1,905 kL (503 kgal) \\
\hline Saltcake liquid & S1-SltCk & 63 kL (17 kgal) \\
\hline Sludge ${ }^{(b)}$ & R1 & 49 kL (13 kgal) \\
\hline \multicolumn{2}{|l|}{ Total Tank ${ }^{(\mathrm{c})}$} & 2,017 kL (533 kgal) \\
\hline \multicolumn{3}{|c|}{$\begin{array}{l}\text { (a) Waste type description is found in Section } 3 \text {. } \\
\text { (b) The sludge waste phase includes both solids and interstitial liquid; } \\
\text { the interstitial liquid is estimated to be } 8 \mathrm{~kL} \text { ( } 2 \text { kgal). } \\
\text { (c) Waste volume as of April } 1,2004 \text {. }\end{array}$} \\
\hline
\end{tabular}

Ten of the 12 S-farm tanks contain waste similar to that in S-109; Tanks S-105, S-106, S-108, and S-110 have the most comparable waste profiles. The tank most similar to S-109 is S-108 because it was filled with 242-S Evaporator saltcake waste at the same time as S-109. Waste type information for the

(a) ARHCo. 1974. Operations Division Waste Status Summary January 1, 1974 through March 31, 197. ARHCD-133A, page 8, Atlantic Richfield Hanford Company, Richland, WA.

(b) Johnson ME. April 8, 2004. "Synopsis of Tank 241-S-109 Waste History." CH2M HILL Inter Office Memo \#7G330-MEJ-04-002, to D. W. Hamilton. CH2M Hanford Group, Richland, WA.

(c) Wood RF. June 19, 2001. "Completion of Fiscal Year 2001-2006 Performance-Based Incentive ORP-05, Section 3, Specific Requirement 1, Completion of Interim Stabilization of Tank 241-S-109.” Letter CHG-0103192 to JJ Short, CH2M Hanford Group, Inc., Richland, WA. 
two tanks is nearly the same. Tank S-109 contains 97.6 percent S1-SltCk (242-S Evaporator S1 saltcake), and 2.4 percent R1 (REDOX plant high-level waste) sludge, while Tank S-108 contains 99.1 percent S1-SltCk and 0.9 percent R1 sludge. Representative samples of Tanks S-109 and S-108 saltcake and sludge have not been obtained since interim stabilization of S-109.

The 1999 Tank S-109 grab-sampling event met the sampling and analysis objectives for the Data Quality Objectives for Tank Farms Waste Compatibility Program (Compatibility DQO) (Mulkey and Miller 1998). Sampling and analysis objectives for PCBs in Tank S-109 were conducted on the archived samples in accordance with the Interim Basis for PCB Sampling and Analyses (Banning 2001) as directed by the PCB Analysis Plan for Tank Archive Samples (Nguyen 2001a). Archived samples from Tank S-109 analyzed for PCB contamination include the composite of the 1999 grab samples; the composite of the 1996 core 158 segments 1, 2, and 4; and the composite of the 1996 core 160, segments 1 and 2 (Nguyen 2001b; Fluor Hanford 2002). Analytical results for the S-109 samples indicate the PCB concentration is $13.4 \mathrm{ppb}(0.0134 \mu \mathrm{g} / \mathrm{g})$ in the saltcake liquid, less than $207 \mathrm{ppb}(0.207 \mu \mathrm{g} / \mathrm{g})$ in the saltcake solids, and less than $172 \mathrm{ppb}(0.172 \mu \mathrm{g} / \mathrm{g})$ in the sludge. In accordance with EPA laboratory methods protocol, results reported below the method detection limit are considered "non-detectable". Therefore, the PCB concentrations in the S-109 saltcake solids and sludge are considered non-detectable and are below the regulated level of $50 \mathrm{ppm}$.

Three grab samples were collected from riser 013 on July 28, 1999 and analyzed according to the Compatibility Grab Sampling and Analysis Plan for Fiscal Year 1999 (SAP) (Sasaki 1999). Analytical results were reported in Tank 241-S-109 Grab Samples 9S-99-1, 9S-99-2, and 9S-99-3, Analytical Results for the Final Report (Steen 1999). Additional sampling and analyses were not necessary to satisfy compatibility issues associated with the transfer of liquid from S-109 to SY-102. An interstitial liquid volume of $129 \mathrm{~kL}$ (34 kgal) was transferred from S-109 to SY-102 between September 2000 and January 2001, and interim stabilization was completed as of June $11,2001 .^{\text {(a) }}$

Core 158 from riser 014 and core 160 from riser 016 were collected on June 28 and July 8, 1996, respectively. Two cores of 12 segments each were expected to be retrieved during the sampling event; however, the saltcake was too hard to be completely sampled by push-mode core sampling. The top four segments of core 158 were obtained before a hard layer prevented further penetration with the sampler. A maximum allowable down-force for the push mode sampling truck was reached repeatedly with little waste penetration when sampling core 160. Segments 1, 2A, 2B, and 2C from core 160 were obtained after adding lithium bromide-traced water to the drill string. For core 158, segments 2 through 4 were obtained after softening the waste in the same manner. The samples were analyzed according to the Tank Safety Screening Data Quality Objective (Dukelow et al. 1995) and the Historical Model Evaluation Data Requirements (Simpson and McCain 1995). The purpose of the historical evaluation was to determine whether the HDW model, based on process knowledge and historical information (Agnew et al. 1997), agreed with current descriptions of tank inventories based on sampling.

(a) Wood RF. June 19, 2001. "Completion of Fiscal Year 2001-2006 Performance-Based Incentive ORP-05, Section 3, Specific Requirement 1, Completion of Interim Stabilization of Tank 241-S-109.” Letter CHG-0103192 to JJ Short, CH2M Hanford Group, Inc., Richland, WA. 
Historical DQO issues (Simpson and McCain 1996) have been replaced by the BBI assessment (Sasaki 2001). The incomplete cores obtained from the sampling event failed to meet the Safety Screening DQO requirements at the time of sampling; however, a subsequent review found the data adequate to satisfy the requirements of the Safety Screening DQO (Reynolds et al. 1999). Analytical results were reported in the Tank S-109, Cores 158 and 160 Analytical Results for the Final Report (Fritts 1996). Figure 2.4 presents a profile of the S-109 cores compared with the expected core profile.

The vapor samples taken from Tank S-109 on June 4, 1996, as specified in the Vapor Sampling and Analysis Plan (Homi 1996), met the requirements for the H\&S Vapor DQO. The vapor samples were analyzed for selected inorganic analytes, permanent gases, and total non-methane organic compounds and the results were reported in Headspace Vapor Characterization of Hanford Waste Tank S-109: Results from Samples Collected on 06/04/96 (Pool et al. 1997).

\section{S-109 RMCS CORE PROFILE}

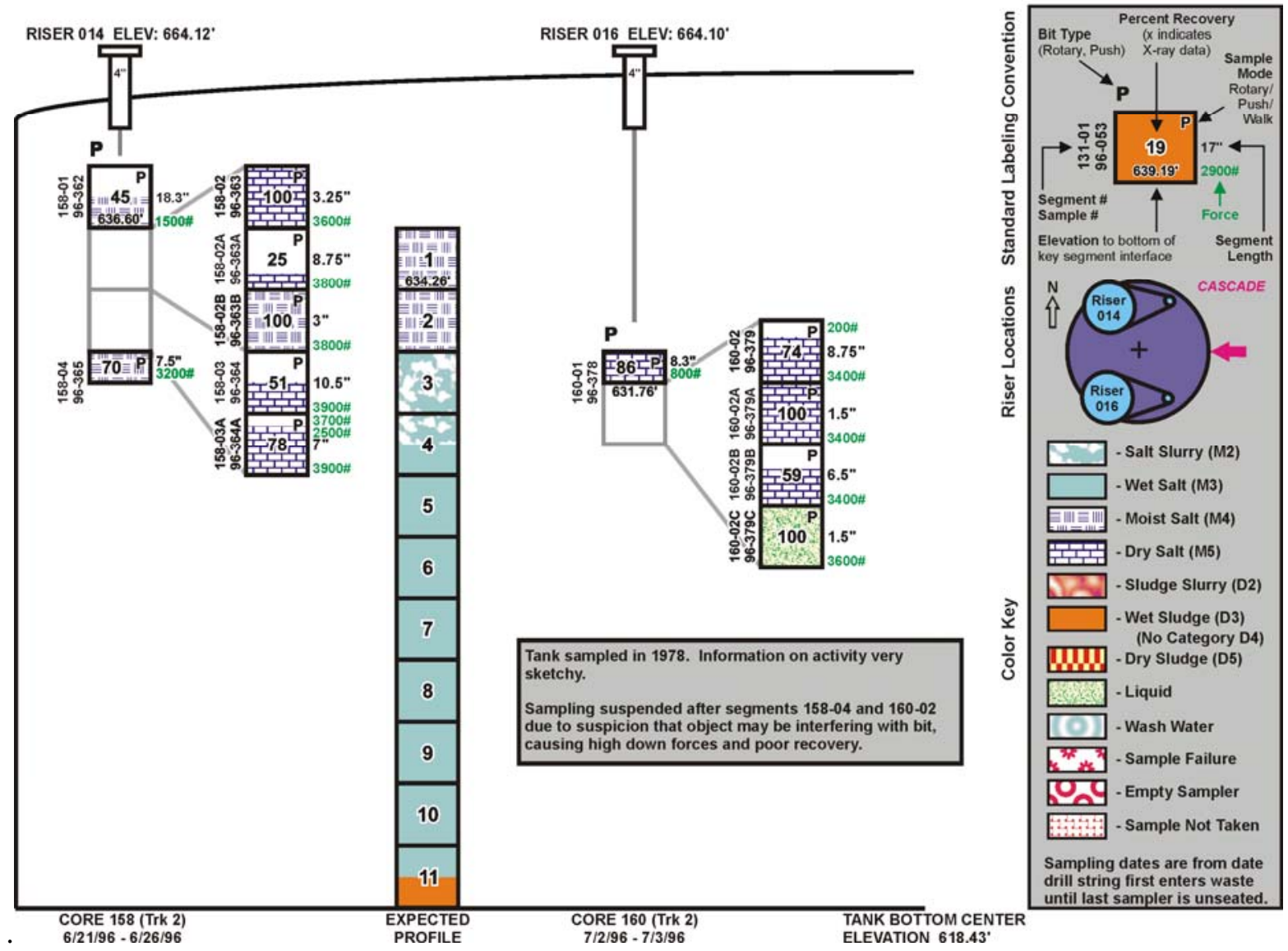

Figure 2.4. Tank S-109 Core Profile 


\subsection{Description of Waste Types}

Tank S-109 received saltcake waste generated from the 242-S Evaporator/Crystallizer from February 1974 until September 1974 and REDOX high-level waste generated between 1952 and 1957. The REDOX waste was removed between November 1973 and February 1974, leaving a heel of sludge and supernatant. The BBI waste descriptions and acronyms for these wastes are provided in Table 3.1.

Table 3.1. BBI Waste Descriptions and Acronyms

\begin{tabular}{|l|l|}
\hline Acronym & \multicolumn{1}{|c|}{ Waste Type Description } \\
\hline S1SltCk & Saltcake waste from the 242-S Evaporator/Crystallizer (1974) \\
\hline R1 & REDOX high-level waste (1952 to 1957) \\
\hline
\end{tabular}

REDOX waste was the high-level component of the process waste from the REDOX process used at Hanford between 1952 and 1957. This solvent extraction process separated uranium from plutonium as well as fission products in the spent fuel from both uranium and plutonium by manipulating their oxidation states. Hexone was used as the organic solvent because it is immiscible with water and extracts uranyl nitrate and plutonyl nitrate selectively from fission-product nitrates at high nitrate concentrations $(0.3 \mathrm{M})$ in the aqueous feed. Aluminum nitrate was used in the process as a salting agent to minimize decomposition of the hexone. Plutonium in the aqueous feed was oxidized to the plutonyl ion with dichromate ion and later reduced to trivalent plutonium nitrate with ferrous sulfamate. The aqueous solution from the initial decontamination contact included the fission products. This solution is the REDOX high-level waste, and it includes many of the chemicals used in the first cycle of the REDOX process. The composition of this waste stream varied, but the nominal concentrations of the primary compounds in the waste are provided in Table 3.2 (Anderson 1990).

Table 3.2. REDOX High-Level Waste Composition

\begin{tabular}{|c|c|}
\hline Compound & Concentration \\
\hline $\mathrm{NaAlO}_{2}$ & $1.2 \mathrm{M}$ \\
\hline $\mathrm{NaOH}$ & $0.69 \mathrm{M}$ \\
\hline $\mathrm{NaNO}_{3}$ & $4.83 \mathrm{M}$ \\
\hline $\mathrm{Na}_{2} \mathrm{CrO}_{7}$ & $0.066 \mathrm{M}$ \\
\hline $\mathrm{Cr}_{2}(\mathrm{OH})_{3}$ & $0.045 \mathrm{M}$ \\
\hline $\mathrm{Na}_{2} \mathrm{SO}_{4}$ & $0.031 \mathrm{M}$ \\
\hline $\mathrm{Fe}(\mathrm{OH})_{3}$ & $0.016 \mathrm{M}$ \\
\hline $\mathrm{U}$ & $0.05 \%$ \\
\hline $\mathrm{Pu}$ & $0.04 \%$ \\
\hline
\end{tabular}


Waste from numerous SSTs was sent to the 242-S Evaporator/Crystallizer, where it was concentrated and transferred to Tank S-109. This waste is primarily sodium nitrate. Solids from this waste stream were analyzed at different times and are reported in several process aids. ${ }^{(\mathrm{a}, \mathrm{b}, \mathrm{c}, \mathrm{d})}$ The range of composition in both the solids and liquids from these analyses is reported in Table 3.3.

Table 3.3. Saltcake Waste Composition

\begin{tabular}{|c|c|c|}
\hline \multirow{2}{*}{ Compound } & \multicolumn{2}{|c|}{ Concentration } \\
\cline { 2 - 3 } & Mother Liquor (M) & Salt (wt\%) \\
\hline $\mathrm{H}_{2} \mathrm{O}$ & $44-55 \%$ & $9-13$ \\
\hline $\mathrm{NaAlO}_{2}$ & $1.1-1.2$ & $1-2$ \\
\hline $\mathrm{NaNO}_{2}$ & $1.1-1.8$ & $0-2$ \\
\hline $\mathrm{NaNO}_{3}$ & $2-5$ & $70-90$ \\
\hline $\mathrm{NaOH}$ & $5-5.6$ & $1-4$ \\
\hline $\mathrm{Na}_{2} \mathrm{CO}_{3}$ & $0.1-0.2$ & $0-7$ \\
\hline $\mathrm{Na}_{2} \mathrm{SO}_{4}$ & $0-0.05$ & $0-1$ \\
\hline $\mathrm{Na}_{3} \mathrm{PO}_{4}$ & $0-0.02$ & $0-0.1$ \\
\hline
\end{tabular}

(a) Buckingham JS. March 13, 1974. “Analyses of Samples from 242-S Slurry Receiving Tanks.” Memo 031374 to MH Campbell, Atlantic Richfield Hanford Company, Richland, WA.

(b) Buckingham JS. September 3, 1974. "Analysis of Salt Sample from 242-S Evaporator Slurry Receiving Tank 109-S.” Memo 090374 to NL Harms, Atlantic Richfield Hanford Company, Richland, WA.

(c) Buckingham JS. January 31, 1975. "Composition of Recycle Liquors Produced by the 242-S EvaporatorCrystallizer.” Memo 013075, Atlantic Richfield Hanford Company, Richland, WA.

(d) Horton JE. December 8, 1976. “Analysis of Salts from Tank 109-S.” Letter 120876 to WR Christensen, Atlantic Richfield Hanford Company, Richland, WA. 


\subsection{Approach}

Existing analytical data from tank waste samples were reviewed and combined with data from similar tank wastes along with process knowledge of the wastes transferred into the tanks to determine whether selected dangerous waste codes assigned to Tank S-109 are applicable.

The analytical data reviewed included DSC results; concentrations of sulfur, sulfate, and cyanide; composition of the headspace (vapor space); and $\mathrm{pH}$. TOC, oxalate, and mercury concentrations were also reviewed. Table 4.1 lists the dangerous waste codes to which each of these analyses were applied. This section discusses the sample analyses methods and the data review approach. Section 5.0 compares the analytical data from tank waste samples to the dangerous waste characteristics.

Table 4.1. Analyses Reviewed in Determining Dangerous Waste Characteristics

\begin{tabular}{|l|l|l||}
\hline Analysis & Waste Code & \multicolumn{1}{|c|}{ Characteristic } \\
\hline DSC & D001/D003 & Ignitability \& Reactivity \\
\hline Sulfur & D003 & Reactivity \\
\hline Sulfate & D003 & Reactivity \\
\hline Cyanide & D003 & Reactivity \\
\hline Headspace & D001/D003 & Ignitability \& Reactivity \\
\hline pH & D002 & Corrosivity \\
\hline
\end{tabular}

\subsection{Differential Scanning Calorimetry (DSC)}

DSC results have been used to determine the energetics of the tank wastes as a function of temperature. DSC scans plot the differential heating rate versus temperature. An example of a typical DSC scan is provided in Figure 4.1.

DSC measures the differential power (heat input) needed to keep a sample and an inert reference substance isothermal as temperature is increased linearly. The data generated by DSC is used to determine heats of reactions, reaction rates, phase transitions, and thermal stabilities. In a DSC scan several transitions may be observed. Each transition indicates at least one separate reaction or phase transition. The area under the peak of each transition is directly proportional to the heat evolved (exothermic) or absorbed (endothermic) by the reaction or phase transition, and the height of the curve is directly proportional to the rate of reaction. In DSC sharp exothermic transitions with large heats of reaction are indicative of unstable materials with vigorous or violent reactions such as explosions or detonations.

The DSC results were reviewed to determine whether any exothermic behavior was observed; if it was, the DSC scans were reviewed and the shape and energy of the transitions determined. If no exothermic behavior was observed or the transitions were broad with low heats of reaction, the waste was considered stable without violent reactions if heated. These results also indicated that the waste was not capable of spontaneous chemical changes that would result in a fire at standard temperature and pressure. If significant endothermic transitions had to occur before the exothermic reaction could occur, the waste could also be considered stable at standard temperature and pressure. 


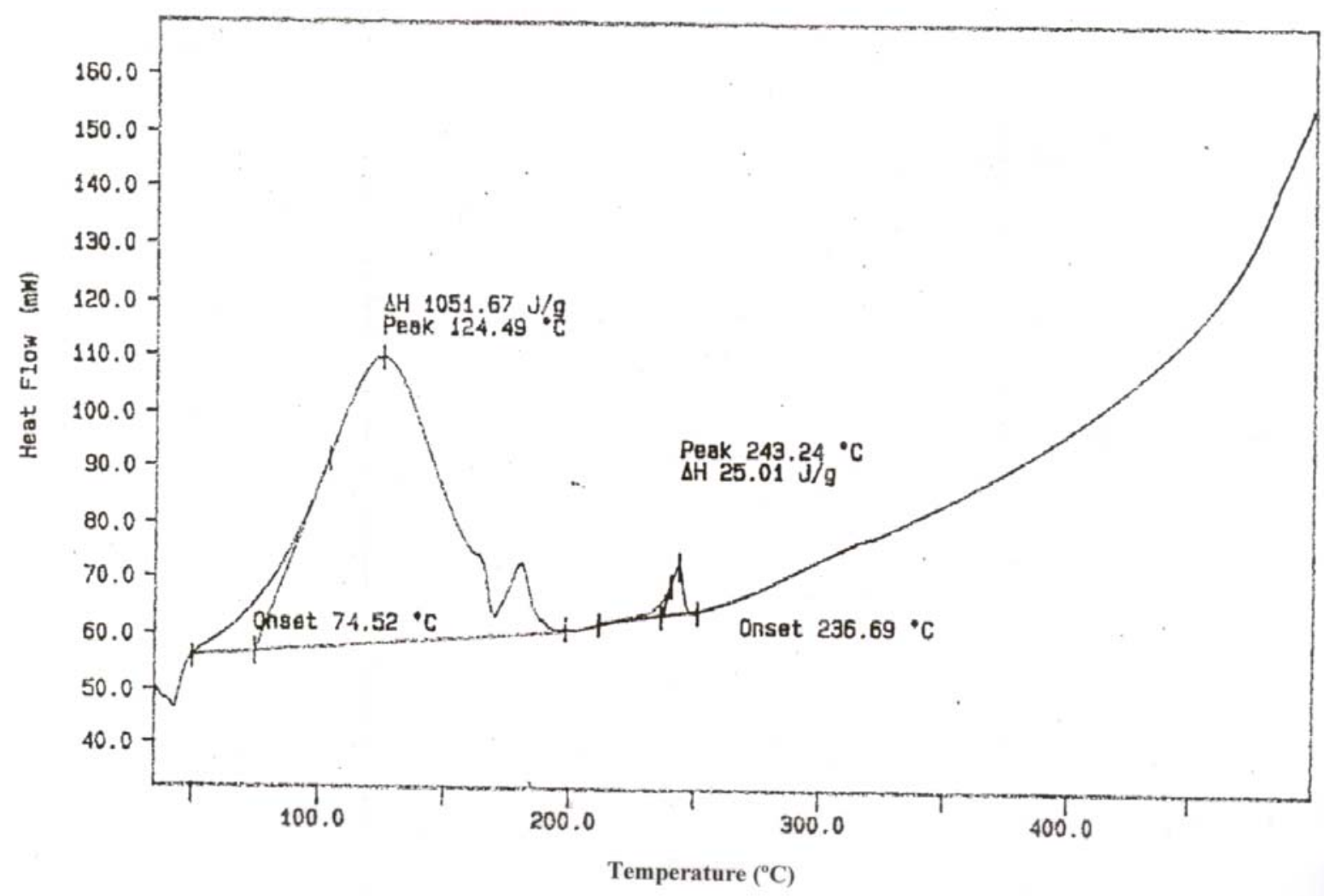

Figure 4.1. DSC of Liquid Grab Sample 9S-99-3. Exotherms are below the baseline and endotherms above. Two endothermic transitions are observed in this DSC.

Because all of these tank wastes contain interstitial liquid as aqueous salt solutions, DSC results obtained on these samples also indicate the reactivity and ignitability of the waste in the presence of water or upon absorption of moisture.

\subsection{Sulfur and Sulfate}

The major sources of sulfur-containing compounds in Hanford tank wastes are sulfuric acid $\left(\mathrm{H}_{2} \mathrm{SO}_{4}\right)$, ferrous sulfamate $\left[\mathrm{Fe}\left(\mathrm{SO}_{3} \mathrm{NH}_{2}\right)_{2}\right]$, sodium sulfate $\left(\mathrm{Na}_{2} \mathrm{SO}_{4}\right)$, and sulfamic acid $\left(\mathrm{HSO}_{3} \mathrm{NH}_{2}\right)$. Sulfate ions (in the form of sulfuric acid) were used in the bismuth phosphate process to form uranyl sulfate $\left[\mathrm{UO}_{2}\left(\mathrm{SO}_{4}\right)_{2}{ }^{2-}\right]$ so that it did not coprecipitate with the plutonium. Uranyl sulfate and most of the sulfate ions from the bismuth phosphate process were contained in the metal waste stream, which was not discharged to Tank S-109. Some sulfate ions would have carried forward with the plutonium in the bismuth phosphate process and been contained in the 1C waste stream. Both ferrous sulfamate and sulfamic acid were used to reduce Pu at oxidation states between IV and VI to the Pu(III) oxidation state in the bismuth phosphate process, with sulfate ions being contained in both the 1C and 2C wastes streams. Both sulfuric acid $\left(\mathrm{H}_{2} \mathrm{SO}_{4}\right)$ and ammonium sulfate $\left[\left(\mathrm{NH}_{4}\right)_{2} \mathrm{SO}_{4}\right]$ were used in the 231-Z plutonium finishing process with plutonium-containing waste from this process recycled to the 224-B and 224-T Concentration Buildings for plutonium recovery. Sulfamic acid was used prior to oxalate precipitation of $\mathrm{Pu}$, and ferrous sulfamate was used in the REDOX and PUREX flow sheets to form the inextractable 
$\mathrm{Pu}\left(\mathrm{NO}_{3}\right)_{3}$ during the solvent extraction process. Sodium sulfate was used in B Plant (1968-1984) to precipitate strontium and separate metal impurities during processes conducted to prepare the strontium for encapsulation. Under tank conditions these sulfur compounds would tend to form sulfates. Tank waste conditions are mildly oxidizing from the abundant nitrate and preclude sulfide formation from sulfate; therefore, a source of sulfide in these tanks is not evident. If sulfide were present in the tanks, under the $\mathrm{pH}$ conditions in the tanks, the predominant form of the sulfide species would be $\mathrm{HS}^{-}$; therefore, the release of $\mathrm{H}_{2} \mathrm{~S}$ would be well below toxic concentrations. Detailed information about sulfate chemistry in the Hanford tank wastes are provided in a letter report prepared by Bruce McNamara for CH2M Hill Hanford Group, Inc. ${ }^{(a)}$

Sulfide concentrations in the waste were estimated by the ratio of sulfur to sulfate because no sulfide determination was made on the samples. Sulfur was determined directly by inductively coupled plasma (ICP) mass spectroscopy on liquid samples and on acid digestions of solid samples. Ion chromatography (IC) was used to measure sulfate in liquid samples from the tank as well as in water digestions of the solid samples from the tank. If all of the sulfur were present as sulfate, the mass ratio of sulfate to sulfur would be 3 to 1 . A mass ratio of less than 3 indicates that sulfur-containing species other than water-soluble sulfate are present in the waste. If the mass ratio is less than 3 , the concentration of sulfur-containing species in the waste other than water-soluble sulfate is calculated from the difference in these two concentrations. The calculated sulfide concentrations are compared with the threshold quantity given in SW-846 (500 mg $\mathrm{H}_{2} \mathrm{~S} / \mathrm{kg}$ of waste formed by acidification), EPA's test method for evaluating solid waste. If the sulfur concentration after subtracting the sulfate concentration (in moles/kg) is less than 0.0147 moles $/ \mathrm{kg}$ of waste $(471 \mathrm{mg} / \mathrm{kg}$ ), the waste cannot be a sulfide-bearing waste. Sulfur and sulfate analyses from the same sample were used for all calculations. Averages were based on the results of these calculations. "Less-than" values were not included in the calculations of the ratios or sulfide estimations.

\subsection{Cyanide}

Cyanide analyses were performed on a limited number of tank samples but were not available for Tank S-109. Process histories were analyzed to determine whether cyanide or cyanide-containing compounds may have been added to this tank.

\subsection{Headspace}

Analyses of the gases present in the headspace of Tank S-109 were available. Headspace samples were taken using sorbent traps for inorganic analytes and SUMMA canisters for permanent gases and total non-methane organic compounds. The canister samples were analyzed by gas chromatography (GC), and the sorbent trap samples were determined by desorbing the analytes of interest from the trap with the appropriate aqueous solution and analyzing the solution by IC or ion selective electrode. The concentrations of these analytes were compared with their threshold limit value-time weighted average (TLV-TWA) reported by the American Conference of Governmental Industrial Hygienists in the 2004 Threshold Limit Values for Chemical Substances in the Work Environment (ACGIH 2004). Threshold limit values for selected analytes are provided in Table 4.2.

(a) McNamara BK. December 2000. "Evolution of Gases from Cyanide and Sulfide Bearing Waste." Letter Report WTP-RPT-011, Battelle - Pacific Northwest Division, Richland, WA. 
Table 4.2. Threshold Limit Values for Selected Headspace Gases

\begin{tabular}{|c|c||}
\hline Analyte & TLV-TWA (ppmv) \\
\hline $\mathrm{NH}_{3}$ & 25 \\
\hline $\mathrm{NO}_{2}$ & 3 \\
\hline $\mathrm{NO}$ & 25 \\
\hline $\mathrm{CO}_{2}$ & 5000 \\
\hline $\mathrm{CO}$ & 25 \\
\hline $\mathrm{CH}_{4}$ & 1000 \\
\hline $\mathrm{H}_{2}$ & Simple asphyxiant \\
\hline $\mathrm{N}_{2} \mathrm{O}$ & 50 \\
\hline
\end{tabular}

Process wastes may be diluted prior to retrieving the waste from the tanks. Henry's Law states that for solutes with measurable vapor pressures the vapor pressure of the solute in dilute solutions is proportional to the mole fraction of that solute. Based on this law used for ideal gases in dilute solutions, the concentration of the gases in the headspace of the waste container will be proportional to the dilution; therefore, for process wastes that are diluted prior to retrieval from the tank, the concentration of the headspace gases can be divided by the dilution factor. If the concentrations of the headspace gases are less than the TLV-TWA for those gases, the waste does not generate toxic gases, vapors, or fumes in enough quantity to present a danger to human health or the environment.

\section{$4.5 \mathrm{pH}$}

Measurements of the $\mathrm{pH}$ were made on liquid grab samples of the tank wastes. The SW-846 method 9045 in Test Methods for Evaluating Solid Waste, Physical/Chemical Methods (EPA 1998) prescribes pH measurements on the liquid fraction of a waste-to-water ratio of 1 to 1 ; therefore, the liquid grab samples provide an accurate estimate of the $\mathrm{pH}$ of the waste in the tank for waste designation purposes. If the $\mathrm{pH}$ of the tank waste samples is between 2 and 12.5, the waste is not corrosive. 


\subsection{S-109 Characterization Data}

The existing analytical results from sampling events were reviewed and compared with the data on waste transfers in Tank S-109. The majority of the data were extracted from the TWINS database and the tank characterization report prepared by PNNL (Field 1999).

The analyses reported in this document were performed on wet slurry and sludge unless otherwise noted. Some of these results are reported on a dry weight basis; therefore, these results are independent of the water content of the samples. Most of the results were reported as concentration of analyte per gram of sample (wet). When the sample is dried, these concentrations increase by the ratio of wet sample mass to dry sample mass (the reciprocal of the weight percent total solids of the sample).

Addition of soil followed by vacuum drying of the retrieved tank wastes is the proposed method for removing the water from the waste prior to vitrification. In this process the majority of the free water will be removed from the waste, and some volatile constituents may evaporate; but the ratio of the nonvolatile constituents (e.g., sulfur and sulfate) will not change.

During the DSC analysis, water is evaporated from the sample as the temperature is increased; therefore, after the first endothermic transition (water loss), the results obtained from the DSC provide the energetics of the dried sample. Soil will also act as a diluent; therefore, these DSC results provide an upper bound for the energetics of the waste during the vacuum drying process.

Thermal analyses were performed in duplicate on direct subsamples from subsegments of cores 158 and 159 and on the three grab samples. Both thermogravimetric analysis (TGA) and DSC were performed on each sample. Two endothermic transitions were observed for all samples; the first occurred between ambient temperature and $150^{\circ} \mathrm{C}$ and coincides with mass loss observed in the TGA, indicating evaporation of the free water from the sample. The enthalpy of this endothermic transition depends on the water content of the sample. The second endothermic transition was observed between $200^{\circ}$ and $330^{\circ} \mathrm{C}$. The enthalpy of this transition was approximately $240 \mathrm{~J} / \mathrm{g}$ of sample on a dry weight basis. This transition is probably due to the loss of waters of hydration, phase transitions, or decomposition of salts and hydroxides to oxides; for example, sodium nitrate melts at $306.8^{\circ} \mathrm{C}$. A third transition was observed on a limited number of samples (five samples plus duplicates out of 37 samples plus duplicates). This transition was exothermic with an enthalpy less than $50 \mathrm{~J} / \mathrm{g}$ of sample (dry weight basis). The onset temperature for these exothermic transitions was greater than $380^{\circ} \mathrm{C}$. These transitions were broad peaks with little amplitude compared with the endothermic reactions. None of the samples exceeded the action limits (480.0 J/g) stated in the tank sampling and analysis plan (TSAP) (Field 1996). Detailed results, including the plots of the DSC and TGA analyses, can be found in Fritts (1996). DSC analyses from Tank S-110 were also reviewed because the cores from Tank S-109 were not complete (see Figure 2.4). Complete cores were obtained from Tank S-110. Similar results were obtained from later Tank S-110 core samples (cores 240 and 241). A higher enthalpy (218 and $359 \mathrm{~J} / \mathrm{g}$ ) of the exothermic reaction was observed on the top segment of an earlier core sample from S-110 (core 140). This same segment was analyzed in Tank S-109, and no exothermic behavior was observed in samples from the top segments of cores 158 and 160. The observed exothermic transition is not indicative of a potentially explosive reaction or ignition hazard at standard temperature or pressure. 
Sulfur analyses were performed on acid and water digests of the subsegment samples from cores 158 and 160. Sulfate analyses were performed on water digests, and both sulfur and sulfate analyses were performed on direct subsamples from the drainable liquid from core 160 and grab samples (9S-99-1, 9S99-2, and 9S-99-3) obtained from this tank. The results from the Tank Interpretive Report in the TWINS database are presented in Table 5.1. The sulfate/sulfur ratio was calculated to determine whether sulfur was present in a form other than sulfate. The ratios indicated the sulfur was present predominantly in the sulfate form. Sulfur and sulfate analyses from Tank S-110 were also reviewed. Similar sulfate/sulfur ratios were observed for this tank. These results indicate that Tank S-109 waste is not sulfide-bearing.

Table 5.1. Sulfur and Sulfate Concentrations

\begin{tabular}{|c|c|c|c|c|c|}
\hline \multicolumn{6}{|c|}{ Core Samples } \\
\hline \multicolumn{3}{|c|}{ Sulfur by Acid Digestion } & \multicolumn{2}{|c|}{ Concentration $(\mu \mathrm{g} / \mathrm{g})$} & \multirow{2}{*}{$\begin{array}{c}\text { Ratio } \\
\left(\mathrm{SO}_{4}{ }^{2-} / \mathrm{S}\right)\end{array}$} \\
\hline Core & Segment & Subsegment & Sulfur & Sulfate & \\
\hline \multirow{10}{*}{158} & \multirow{2}{*}{1} & Lower Half & $5,780^{(\mathrm{a})}$ & 15,400 & 2.66 \\
\hline & & \begin{tabular}{|l} 
Upper Half \\
\end{tabular} & 11,600 & 34,000 & 2.93 \\
\hline & $2 \mathrm{~A}$ & Segment & $3,890^{(a)}$ & $13,900^{(a)}$ & 3.57 \\
\hline & \multirow{2}{*}{ 2B } & Lower Half & 962 & 3,770 & 3.92 \\
\hline & & Upper Half & 1,190 & 4,100 & 3.45 \\
\hline & 2 & Segment & $3,600^{(b, c)}$ & 13,700 & 3.81 \\
\hline & $3 \mathrm{~A}$ & Segment & 928 & 3,440 & 3.71 \\
\hline & \multirow{2}{*}{3} & Lower Half & $2,310^{(\mathrm{a})}$ & $7,140^{(a)}$ & 3.09 \\
\hline & & Upper Half & $1,050^{(\mathrm{a}, \mathrm{c}, \mathrm{d})}$ & $<3,340$ & \\
\hline & 4 & Segment & 79.9 & $<1,140$ & \\
\hline \multirow{4}{*}{160} & 1 & Segment & $1,460^{(\mathrm{c}, \mathrm{d})}$ & $5,880^{(a)}$ & 4.03 \\
\hline & \multirow{2}{*}{ 2B } & Lower Half & 1,630 & 6,090 & 3.74 \\
\hline & & Upper Half & $1,080^{(\mathrm{c}, \mathrm{d})}$ & 3,360 & 3.11 \\
\hline & 2 & Segment & $906^{(\mathrm{b}, \mathrm{c})}$ & $3,590^{(\mathrm{a})}$ & 3.96 \\
\hline \multicolumn{6}{|c|}{ Sulfur by Water Digestion } \\
\hline 158 & 2 & Segment & 4,490 & 13,700 & 3.05 \\
\hline \multirow{2}{*}{160} & $2 \mathrm{~A}$ & Segment & 601 & 2,290 & 3.81 \\
\hline & 2 & Segment & $878^{\mathrm{a}}$ & 3,590 & 4.09 \\
\hline \multicolumn{6}{|c|}{ Liquids } \\
\hline \multicolumn{3}{|c|}{ Sample } & \multicolumn{2}{|c|}{ Concentration $(\mu \mathrm{g} / \mathrm{ml})$} & \\
\hline \multicolumn{3}{|c|}{ 9S-99-1 } & 518 & 1,570 & 3.03 \\
\hline \multicolumn{3}{|c|}{ 9S-99-2 } & 549 & 1,600 & 2.91 \\
\hline \multicolumn{3}{|c|}{$9 S-99-3$} & 651 & 2,080 & 3.20 \\
\hline \multicolumn{3}{|c|}{ Core 160, Segment 2C, Drainable Liquid } & 3,610 & 4,760 & 1.32 \\
\hline \multicolumn{6}{|c|}{$\begin{array}{l}\text { (a) The relative percent difference (RPD) for the primary and duplicate was greater than the } \\
\text { quality control (QC) limit range. } \\
\text { (b) The spike recovery was above the QC range. } \\
\text { (c) The matrix spike failed and the serial dilution passed. } \\
\text { (d) The spike recovery was below the QC range. }\end{array}$} \\
\hline
\end{tabular}


Tank S-109 was not on the Ferrocyanide Watch List (Fowler 1993); therefore, no cyanide analyses were performed on this or other tanks with similar waste compositions. Sodium or potassium ferrocyanide $\left(\mathrm{Na}_{4} \mathrm{Fe}(\mathrm{CN})_{6}\right.$ or $\left.\mathrm{K}_{4} \mathrm{Fe}(\mathrm{CN})_{6}\right)$ were added to some of the waste feeds along with $\mathrm{NiSO}_{4}$ and $\mathrm{NaOH}$ to precipitate sodium and cesium nickel ferrocyanides $\left(\mathrm{Na}_{2} \mathrm{NiFe}(\mathrm{CN})_{6}\right.$ and $\left.\mathrm{Cs}_{2} \mathrm{NiFe}(\mathrm{CN})_{6}\right)$, thus scavenging the radiocesium from the aqueous wastes. Process histories indicate that S-109 did not accept cyanide-containing wastes and was not part of the cesium precipitation campaigns.

No analysis was available for mercury concentrations in Tank S-109 or any similar tanks. Estimated values are reported in the BBI. The $\mathrm{pH}$ of the waste in Tank S-109 was measured on liquid grab samples. No $\mathrm{pH}$ data are available for the core samples, but the $\mathrm{pH}$ should be fairly consistent over the entire depth of the tank. The measured $\mathrm{pH}$ was $13.01 \pm 0.05$. At this $\mathrm{pH}$ the waste is characteristic of corrosivity.

Gas analysis was performed on vapor taken from the headspace of Tank S-109 (Pool et al. 1997). Results of these analyses are summarized in Table 5.2. These gases represent less than $11 \%$ of the LFL.

Table 5.2. Headspace Analysis

\begin{tabular}{||l|l||}
\hline \multicolumn{1}{|c|}{ Analyte } & \multicolumn{1}{c|}{$\begin{array}{c}\text { Vapor Concentration } \\
\text { (ppmv) }\end{array}$} \\
\hline $\mathrm{NH}_{3}$ & $44.9 \pm 2.2$ \\
\hline $\mathrm{NO}_{2}$ & $<0.16$ \\
\hline $\mathrm{NO}$ & $<0.16$ \\
\hline $\mathrm{H}_{2} \mathrm{O}$ & $10.8 \pm 0.2 \mathrm{mg} / \mathrm{L}$ \\
\hline $\mathrm{CO}_{2}$ & $<17$ \\
\hline $\mathrm{CO}$ & $<17$ \\
\hline $\mathrm{CH}_{4}$ & $<25$ \\
\hline $\mathrm{H}_{2}$ & $<17$ \\
\hline $\mathrm{N}_{2} 0$ & $<17$ \\
\hline Total non-methane organic compounds & $3.74 \mathrm{mg} / \mathrm{m}^{3}$ \\
\hline
\end{tabular}

The retrieval process planned for Tank S-109 will result in a 3.37:1 water to waste dilution. ${ }^{(a)}$ Based on Henry's Law for dilute solutions, concentrations of an ideal gas will be diluted proportional to the dilution of the solute; therefore, an estimate of the concentration of these gases above the process waste retrieved from the tank includes a dilution of approximately 3.37 to the gases measured in the headspace of the tank. At this dilution all of the toxic gases should be below the TLV.

Because no exothermic behavior was observed at normal temperature and pressure and the quantity of flammable gases present in the headspace is less than $11 \%$ of the LFL, this waste is not ignitable. The energetics of the system also indicates that the waste is thermally stable, does not form potentially explosive mixtures with water, does not detonate or undergo an explosive reaction if heated, and does not detonate or decompose explosively at standard temperature and pressure. The waste is not a cyanide- or sulfide-bearing waste. The process wastes (diluted 3.37 to 1 ) retrieved from the tank should not generate toxic gases, vapors, or fumes that are hazardous to human health.

(a) Personal communication with Tom May of CH2M HILL. 


\subsection{Conclusions}

Exothermic transitions were observed in a limited number of samples from Tank S-109, but the predominant transitions in the DSC scans were endotherms. Two endothermic transitions were observed for all samples. The first coincides with a large mass loss observed in the TGA, indicating the evaporation of the free water from the sample. This is the major transition in all of the samples. The second endothermic transition was observed at higher temperatures than the water loss endotherm and is probably due to phase transitions, decomposition of salts or hydroxides, or loss of more tightly bound water. The enthalpy of this transition ( $<50 \mathrm{~J} / \mathrm{g}$ of dry sample) was much smaller than the enthalpy of the water loss transition. An exothermic transition was observed in 5 out of 37 samples. This exotherm was observed at higher temperatures than the two endotherms and had an onset temperature that was greater than $380^{\circ} \mathrm{C}$. This exothermic transition had a broader peak with a smaller amplitude than the endothermic reactions and is not indicative of a potentially explosive reaction or ignition hazard at standard temperature and pressure.

Data were not available on the concentration of sulfide in this tank waste, but the sulfur and sulfate analyses indicated that the majority of the sulfur is present as sulfate. Based on the $\mathrm{pH}$, temperature, and mildly oxidizing conditions of the waste, sulfate is stable and will not react to form sulfide. Tank S-109 was not included on the Ferrocyanide Watch List (Fowler 1993), and cyanide-containing wastes and/or process streams were not introduced into this tank. Based on these data, Tank S-109 contains no sulfideor cyanide-bearing wastes.

Based on the $\mathrm{pH}$ of the liquid grab samples, the waste in Tank S-109 does exceed the 12.5 limit characteristic of corrosive wastes; therefore, this waste must be considered corrosive.

Gas analysis of the headspace vapors in this tank indicates that all of the toxic vapors except ammonia are well below the TLV-TWA. Ammonia is produced in Hanford wastes by several pathways and is retained in the waste due to its solubility in water. The major pathways for ammonia generation include thermal and radiolytic reactions involving nitrite ions and nitrogen-containing complexants (Stock 1997). Dilution of the tank wastes prior to retrieval will be required to meet this criterion, but the dilution required (a factor of 1.9) is less than that currently planned for retrieval of this waste (3.37 to 1 water to waste ratio); therefore, the process waste retrieved from the tank should not generate ammonia gas at concentrations harmful to human health.

Analysis of the existing characterization data from core, grab, and vapor samples from Tank S-109 supports the removal of the dangerous waste codes for ignitability (D001) and reactivity (D003). 


\subsection{References}

Agnew SF, J Boyer, RA Corbin, TB Duran, JR FitzPatrick, KA Jurgensen, TP Ortiz, and BL Young. 1997. Hanford Tank Chemical and Radionuclide Inventories: HDW Model Rev. 4. LA-UR-96-3860, Los Alamos National Laboratory, Los Alamos, NM.

American Conference of Governmental Industrial Hygienists (ACGIH). 2004. TLVs and BEIs Based on Documentation of the Threshold Limit Values for Chemical Substances and Physical Agents and Biological Exposure Indices. ACGIH, Cincinnati, OH.

Anderson JD. 1990. A History of the 200 Area Tank Farms. WHC-MR-132, Westinghouse Hanford Company, Richland, WA.

Banning DL. 2001. Interim Basis for PCB Sampling and Analysis. RPP-7614 Rev. 1, CH2M HILL Hanford Group, Inc., Richland, WA.

Brevick CH, JW Funk, and JL Stroup. 1997. Historical Tank Content Estimate for the Northwest Quadrant of the Hanford 200 West Area. HNF-SD-WM-ER-351 Rev. 1, Fluor Daniel Northwest Inc., Richland, WA.

Dukelow GT, JW Hunt, H Babad, and JE Meacham. 1995. Tank Safety Screening Data Quality Objective. WHC-SD-WM-SP-004 Rev. 2, Westinghouse Hanford Company, Richland, WA.

Field JG. 1996. Tank 241-S-109 Push Mode Core Sampling and Analysis Plan. WHC-SD-WM-TSAP-087 Rev. 0, Westinghouse Hanford Corporation, Richland, WA.

Field JG. 1999. Tank Characterization Report for Single-Shell Tank 241-S-109. HNF-SD-WM-ER-627 Rev. 0D, Lockheed Martin Hanford Corporation, Richland, WA.

Fowler KD. 1993. Ferrocyanide Tank Waste Stability. WHC-EP-0347 Supplement 2, Westinghouse Hanford Company, Richland, WA.

Fluor Hanford. 2002. Polychlorinated Biphenyl Baseline Project FY2001 Analytical Results for Final Report. HNF-7445, Fluor Hanford Inc., Richland WA.

Fritts LL. 1996. Tank 241-S-109, Cores 158 and 160, Analytical Results for the Final Report. WHC-SD-WM-DP-194 Rev. 1, Westinghouse Hanford Company, Richland, WA.

Hill JG, S Anderson, and BC Simpson. 1995. The Sort on Radioactive Waste Type Model: A Method to Sort Single-Shell Tanks into Characteristics Groups. PNL-9814, Pacific Northwest National Laboratory, Richland, WA.

Homi CS. 1996. Tank 241-S-109 Vapor Sampling and Analysis Plan. WHC-SD-WM-TP-335 Rev. 2, Westinghouse Hanford Company, Richland, WA. 
Mulkey CH and MS Miller. 1998. Data Quality Objectives for Tank Farms Waste Compatibility Program. HNF-SD-WM-DQO-001 Rev. 2A, Lockheed Martin Hanford Corporation for Fluor Daniel Hanford, Inc., Richland, WA.

Nguyen DM. 2001a. PCB Analysis Plan for Tank Archive Samples. RPP-7684 Rev. 0A, CH2M HILL Hanford Group, Inc., Richland, WA.

Nguyen DM. 2001b. Characterization Plan for Establishing a PCB Baseline Inventory in Hanford Waste Tanks. RPP-6693 Rev. 1,CH2M HILL Hanford Group, Inc., Richland, WA.

Pool KH, BL Thomas, JC Evans, KB Olsen, JS Fruchter, and KL Silvers, 1997. Headspace Vapor Characterization of Hanford Waste Tank 241-S-109: Results from Samples Collected on 6/4/96. PNNL-11257, Pacific Northwest National Laboratory, Richland, WA.

Reynolds DA, WL Cowley, JA Lechelt, BC Simpson, and C DeFigh-Price. 1999. Evaluation of Tank Data for Safety Screening. HNF-4217, Lockheed Martin Hanford Corporation, Richland, WA.

Sasaki LM. 1999. Compatibility Grab Sampling and Analysis Plan for Fiscal Year 1999. HNF-3528, Lockheed Martin Hanford Corp., Richland, WA.

Sasaki LM. 2001. Accelerated Best-Basis Inventory Baselining Task. RPP-7625 Rev. 2, CH2M HILL Hanford Group, Inc., Richland, WA.

Simpson BC and DJ McCain. 1995. Historical Model Evaluation Data Requirements. WHC-SD-WM-DQO-018 Rev. 0, Westinghouse Hanford Company, Richland, WA.

Simpson BC and DJ McCain. 1996. Historical Model Evaluation Data Requirements. WHC-SD-WM-DQO-018 Rev. 1, Westinghouse Hanford Company, Richland, WA.

Steen FH. 1999. Tank 241-S-109, Grab Samples, 9S-99-1, 9S-99-2 and 9S-99-3 Analytical Results for the Final Report. HNF-1679 Rev. 0, Fluor Daniel Hanford, Inc., Richland, WA.

U.S. Environmental Protection Agency (EPA). 1998. Test Method for Evaluating Solid Waste, Physical/Chemical Methods. SW-846, EPA Office of Solid Waste and Emergency Response, Washington, DC.

Washington State Department of Ecology. April 2003. “Dangerous Waste Regulations.” Chapter 173303-WAC, Publication Number 92-91, Washington State Department of Ecology, Olympia, WA. 


\section{Distribution}

No. of

Copies

ONSITE

DOE Richland Operations Office

BM Mauss

H6-60

10 CH2M HILL

KD Boomer

H6-19

PM Branson

WE Bryan

ME Johnson

JG Kristofzski

RE Raymond

DB Smet

AR Tedeschi (3)
No. of

Copies

27 Pacific Northwest National Laboratory

LM Bagaasen (3)

K6-28

SQ Bennett

K6-50

TM Brouns

K9-69

GH Bryan

P7-25

CH Delegard

P7-25

JR Deschane

P7-25

GB Josephson

K6-69

ME Lerchen

K6-75

LA Mahoney

K7-15

GK Patello

P7-27

AP Poloski

P7-25

SD Rassat

K6-28

RL Russell

K6-24

JM Tingey (10)

P7-25

Information Release (2)

K1-06 